Fish and Fisheries

July 2017, Volume 18, Issue 4, Pages 638-655

http://dx.doi.org/10.1111/faf.12194

Achimer

http://archimer.ifremer.fr/doc/00357/46834/

(C) 2016 John Wiley \& Sons Ltd

\title{
Thirty years of fleet dynamics modelling using discrete- choice models: What have we learned?
}

\author{
Girardin Raphael ${ }^{1}$, Hamon Katell ${ }^{2}$, Pinnegar John ${ }_{7}^{3}$, Poos Jan Jaap ${ }_{*}^{4}$, Thébaud Olivier ${ }^{5}$, Tidd Alex ${ }^{3,6}$, \\ Vermard Youen ${ }^{7}$, Marchal Paul ${ }^{1}$
}

${ }^{1}$ Ifremer; Channel \& North Sea Fisheries Research Unit; 150 Quai Gambetta BP 69962321 Boulognesur-mer ,France

${ }^{2}$ Wageningen UR; LEI; P.O. Box 297032502 LS The Hague,the Netherlands

${ }^{3}$ CEFAS; Pakefield Road Lowestoft Suffolk NR33 OHT, UK

${ }^{4}$ Wageningen UR; IMARES; PO Box 68 1970AB IJmuiden, the Netherlands

${ }^{5}$ Ifremer; UMR 6308; AMURE; Unité d'Economie Maritime; BP 70 F-29280 Plouzané Cedex ,France

${ }^{6}$ South Pacific Commission; BP D5 98848 Noumea ,New Caledonia

${ }^{7}$ IFREMER; Fisheries Ecology and Modelling Unit; Centre Atlantique; rue de l'lle d'Yeu BP 21105 44311 Nantes Cedex 03, France

*Corresponding author : Paul Marchal, email address : paul.marchal@ifremer.fr

\begin{abstract}
:
Anticipating fisher behaviour is necessary for successful fisheries management. Of the different concepts that have been developed to understand individual fisher behaviour, random utility models (RUMs) have attracted considerable attention in the past three decades, and more particularly so since the 2000s. This study aimed at summarizing and analysing the information gathered from RUMs used during the last three decades around the globe. A methodology has been developed to standardize information across different studies and compare RUM results. The studies selected focused on fishing effort allocation. Six types of fisher behaviour drivers were considered: the presence of other vessels in the same fishing area, tradition, expected revenue, species targeting, costs, and risk-taking. Analyses were performed using three separate linear modelling approaches to assess the extent to which these different drivers impacted fisher behaviour in three fleet types: fleets fishing for demersal species using active gears, fleets fishing for demersal species using passive gears and fleets fishing for pelagic species. Fishers are attracted by higher expected revenue, tradition, species targeting and presence of others, but avoid choices involving large costs. Results also suggest that fishers fishing for demersal species using active gears are generally more influenced by past seasonal (long-term) patterns than by the most recent (short-term) information. Finally, the comparison of expected revenue with other fisher behaviour drivers highlights that demersal fishing vessels are risk-averse and that tradition and species targeting influence fisher decisions more than expected revenue.
\end{abstract}


Introduction

Materials and Methods

Materials

Standardizing fisher behaviour drivers

Standardizing model outputs

Analysis design

Attraction or repulsion?

Short-term or long-term decisions?

What is the relative influence of expected gross revenue and of other drivers on fisher behaviour?

Results

Attraction or repulsion?

Short-term or long-term decisions?

What is the relative influence of expected gross revenue and of other drivers on fisher behaviour?

Discussion

Attraction or repulsion?

Is fisher behaviour more influenced by seasonal or immediate knowledge?

Which drivers for which fleets?

Where to from here?

Conclusion

Acknowledgements

\section{References}




\section{Introduction}

There has been an increasing societal and public demand from governments, industries and nongovernmental organizations to provide sound and integrated scientific support for ecosystem-based management (EBM) (Arkema et al. 2006; Browman and Stergiou 2004; Fulton et al. 2014; Garcia and Cochrane 2005). The concept of Ecosystem Approach to Fisheries (EAF) or Ecosystem Approach to Fisheries Management (EAFM) was adopted to account more explicitly for the interdependence between human and environmental considerations, therefore to consider the environmental impacts of fisheries as well as the impacts of the environment on fisheries (Garcia et al. 2003; Pomeroy et al. 2014; Ward et al. 2002). A prerequisite to the effective application of the EAFM is to better understand the different components of the ecosystem (Degnbol et al. 2006; Fulton et al. 2014). Fishers are key components of marine ecosystems: understanding and anticipating their behaviour is particularly important when implementing management regulations (Hilborn 2007). For example, the introduction of spatial closures can result in redistributions of fishing effort, with adverse and unforeseen knock-on effects on other ecosystem components (Fulton et al. 2011; Hilborn 2007; Leslie and McLeod 2007).

Yet, the adaptability of fishers to regulations and environmental variability has often been disregarded, leading to fisheries management failures (Branch et al. 2006; Daw and Gray 2005; Fulton et al. 2011; Hardin 1968). Different studies of stock collapses, e.g. Caspian Sea anchovy (Daskalov and Mamedov 2007), Californian sardine (Radovich 1982), North Sea herring (Dickey-Collas et al. 2010), and North Atlantic cod (Poulsen et al. 2006; Walters and Maguire 1996), suggest that while recruitment failures, competition with other species (Hjermann et al. 2013), and exceptional environmental conditions (Beaugrand et al. 2003) have caused fish stock depletion, a lack of understanding of fisher behaviour and their reactivity to complex management regimes is also a key cause of management failures (Allen and McGlade 1987; Degnbol et al. 2006; Hilborn 2007; Peterson 2000). 
The mechanisms of change in the behaviour of human agents have been widely studied using a range of approaches, one of the most dominant being discrete-choice modelling (McFadden 1974; Greene 2003; Train 2003). Discrete-choice models building in a random utility function, also known as Random Utility Models (RUMs), have been applied in various disciplines including preferences of households and consumers (Bougherara et al. 2009; Gracia and de Magistris 2008; Zhang et al. 2009), school choice (Cohen-Zada and Sander 2008; Glick and Sahn 2006), or travelling options (Ettema et al. 2007; McFadden 1974). A founding principle of RUMs is that an agent facing multiple choices assigns a utility to each alternative, and then chooses that with the greatest utility. RUMs have also increasingly been applied to fisheries, to analyse how fishers choose their fishing grounds (Hutton et al. 2004; Tidd et al. 2012; Tidd et al. 2015; Wilen et al. 2002), their target species (Marchal et al. 2014; Pradhan and Leung 2004; Vermard et al. 2008), their fishing gear (Andersen et al. 2012; Eggert and Tveteras 2004), or a combination of these (Holland and Sutinen 1999; Girardin et al. 2015; Marchal et al. 2009). Many other fleet dynamics studies have been conducted using RUMs, see van Putten et al. (2012) for a qualitative review published in this journal. These studies have investigated the relative weights of different fisher behaviour drivers, hereby simply referred to as "drivers", for a variety of countries, fishing fleets, fishing periods, and underlying model structures. The objective of this study is to review and compare, in a standardized fashion, the evidence drawn from RUM-based fleet dynamics investigations which have been conducted in the past three decades. In these studies, the dynamics of effort allocation are reflected by different types of discrete choices, including the decision to fish or not. If fishers decide to go fishing, they have to decide what type of métier (i.e., combination of fishing ground, fishing gear, and/or target species) to choose from. In our analysis, the main key drivers are highlighted, and we investigate whether any common patterns can be detected across case studies. Particular attention is paid to how expected revenue influences fisher behaviour compared to other possible drivers (e.g., traditions, target species), and also whether fishers are more likely to make decisions based on short-term (daily to monthly) rather than longerterm (seasonal) information. To our knowledge, no comparison of the explanatory variables driving 
fisher behaviour has ever been performed before. Although some authors have compared the outputs derived from different RUMs (Greene 2003; Greene and Hensher 2003; Koppelman and Wen 1998; McFadden 1974; Swait and Louviere 1993; Train 2003; Wen and Koppelman 2001), these comparisons were performed either using a single model structure (to compare results across different fleets), or using a single set of input data (to compare model differences).

\section{Materials and Methods}

\section{Materials}

The data used for this study come from a selection of fleet dynamics studies reviewed by van Putten et al. (2012). These authors present an overview of different models and theories applied over the past three decades to explain and forecast fishing behaviour. In addition, the more recent fisheries science and economics literature were surveyed, to include fleet dynamics studies that were conducted since 2010, and hence were not considered by van Putten et al. (2012). This search for additional references was based on several criteria. First, the publications selected focused on fishing effort allocation in terms of métiers. In some studies, the decision to fish or not was also part of the choice set (Table 1). Only papers highlighting the factors driving fisher decision-making were selected. Our research was further constrained to analyses based on discrete-choice models, mainly RUMs (Greene 2003). Finally, only papers where the entire model output was presented (i.e., parameter estimates and standard deviations associated to all explanatory variables) were retained.

Overall, 26 papers were included in our selection (Table 1). These studies relate mainly to fishing fleets operating in the EU, North America and Oceania, using data collected between 1976 and 2010. Across all 26 papers, a total of 61 case studies were available, with a variety of models being fitted to data available for various fishing fleets. The most commonly used RUM techniques were the conditional (Girardin et al. 2015; Hutton et al. 2004; Marchal et al. 2014; Vermard et al. 2008) and multinomial (Berman 2007; Dupont 1993; Maravelias et al. 2014; Mistiaen and Strand 2000; Prellezo et al. 2009) logit models, nested logit models (Andersen et al. 2012; Bucaram et al. 2013; Campbell 
and Hand 1999; Curtis and McConnell 2004; Eales and Wilen 1986; Holland and Sutinen 1999, Holland and Sutinen 2000; Smith 2002; Smith and Wilen 2003; Wilen et al. 2002) and the mixed logit model (Eggert and Tveteras 2004; Marchal et al. 2014; Pradhan and Leung 2004; Tidd et al. 2012). The nested logit and the mixed logit models were often used to relax the non-IIA (independence of irrelevant alternative choices property) assumption associated with preference heterogeneity across fleets (Greene 2003; Train 2003). For the purpose of this study, the different fleets examined in the 26 articles were grouped into three main categories: fleets fishing for demersal species using active gears (shrimp, demersal, otter and beam trawlers; dredgers; and demersal seiners), fleets fishing for demersal species using passive gears (pots; scuba diving; gill and trammel netters) and fleets fishing for pelagic species (tuna purse seiners; seiners; pelagic trawlers and longliners) (Table 1).

\section{Standardizing fisher behaviour drivers}

We first classified the explanatory variables that describe fisher behaviour in the models being reviewed into a small number of categories (Tables 1 and 2). The first category is their experience, otherwise termed habits or tradition. Tradition is usually included in the utility function as past effort patterns (Holland and Sutinen 1999; Tidd et al. 2012; Vermard et al. 2008). The second category is economic opportunity. Into this revenue category were gathered variables such as past gross revenue or value per unit effort. The third category consists of fishing costs, which negatively contribute to overall fishing profits. Fishing costs were introduced through proxies including fuel price and/or costs, time spent at sea or distance from harbour (Berman 2007; Bucaram et al. 2013). Fishers' attitude towards risk has also been considered as driving their decisions. Fishers have often been categorized in two categories: risk-averse or risk-seeking (Andersen 1982; Branch et al. 2006; Dupont 1993; Hilborn and Ledbetter 1979; Mistiaen and Strand 2000). Risk-averse fishers would be expected to choose stable alternatives, while risk-seekers would select more variable options provided these are associated with higher expected returns. Risk-seeking behaviour, however, appears to be rare within fisheries and may be confounded by poorly informed decisions (Branch et al. 2006). By contrast risk-aversion is considered to be more widely spread across fisheries, as fishers 
seem to seek areas likely to generate a stable revenue (Cinar et al. 2013; Dowling et al. 2015; Dupont 1993; Hilborn and Ledbetter 1979; Ran et al. 2011). Fisher perception of risk has usually been represented by the variance of past revenues, when fishing in a given area or by using a given gear (Holland and Sutinen 1999; Holland and Sutinen 2000; Pradhan and Leung 2004), and it has often been incorporated using mixed logit models (Hensher and Greene 2003; Ran et al. 2011; Tidd et al. 2015). In addition to their own experience, fishers can gain information by scrutinizing the activity of other fishers, and then moving into areas where fishing vessels are most concentrated (Vignaux 1996). On the other hand, the presence of too many vessels or other activities (maritime traffic, aggregate extraction, wind farms) could result in congestion (Curtis and Hicks 2000; Marchal et al. 2014; Poos and Rijnsdorp 2007; Poos et al. 2010). The presence of other agents in fishing areas is usually approximated by a metric representing their activity (e.g., total fishing effort or number of vessels in the case of fisheries). Finally, the last group of drivers considered is species targeting, which gathers variables referring to price, catch, or Catch Per Unit of Effort (CPUE) for a particular species. Indeed, fishers may target specific species assemblages they have a market for or, on the contrary, avoid them as a result of management plans or quota availability.

In addition to the categorization of fisher behaviour drivers into the six groups summarized above, some of these groups were also discriminated based on whether fishers use long-term (seasonal) information made available during the previous year, or short-term knowledge from the previous month, day or fishing trip (Holland and Sutinen 2000; Tidd et al. 2012). In our review, this time-scale differentiation has been applied to the tradition variable group, as a result of data availability.

\section{Standardizing model outputs}

Comparing the outcomes of 61 RUM-based studies (s) of fleet dynamics, using different data inputs, model structures and explanatory variables, implies several challenges.

First, a common standard score needs to be found to compare the respective effects of the different factors potentially influencing fisher behaviour across all models. For this, the value of the test $(\mathrm{t}$ value or $z$ value) used to assess the significance of the RUM estimated coefficients, was selected 
(e.g., Holland and Sutinen 1999). This is calculated as the parameter estimate value $(\mu)$ divided by standard deviation $(\sigma)$. In the reviewed modelling studies $(s)$, more than one explanatory variable $(v)$ is generally associated to a single drivers group $(g)$. Only the explanatory variables with a significant effect ( $p$-value $<0.05$ ) on fisher behaviour were considered. In cases where multiple significant variables $(v)$ belonging to the same group of drivers existed, the variable $\left(v^{*}\right)$ for which the ratio between estimated mean $(\mu)$ and standard deviation $(\sigma)$ of the coefficient was highest was assigned to a driver group $(g)$ in each study $(s)$ (Table 2). The score used for subsequent analyses may be formulated as equation (1):

Score $_{s, m, f, g}=\operatorname{Max}_{v \in g}\left(\left|\mu_{s, m, f, g, v} / \sigma_{s, m, f, g, v}\right|\right)=\left|\mu_{s, m, f, g, v^{*}} / \sigma_{s, m, f, g, v^{*}}\right|$

Where $m, f$ and $g$ refer to the modelling method (conditional logit, mixed logit, multinomial logit, nested logit), fleet category (active demersal, passive demersal, pelagic) and any drivers group (revenue, vessel density, cost, risk, targeting, tradition) considered in study s, respectively.

\section{Analysis design}

Three analyses were performed to address three questions concerning fisher behaviour. The first question is whether fleet dynamics drivers consistently have the same positive (attracting) or negative (repulsing) effects on fishers choosing a given alternative. Second, short-term and long term influences on fisher behaviour were investigated. Finally, the importance of different drivers was estimated relative to expected revenue across the different RUM studies. The reason for choosing expected revenue as the reference driver is that it is investigated in all fleet dynamics studies under consideration (Table 1), and also since it is used in many studies to calculate welfare effects.

\section{Attraction or repulsion?}

We analysed the sign of the estimated coefficient value associated to each explanatory variable $\left(v^{*}\right)$ selected after calculating the score $\left(\mu_{s, m, f, g, v^{*}}\right.$, see equation (1)). This was based on the comparison, 
for each driver group $g$, of the relative proportion of negative $\left(P_{g}^{-}\right)$and positive $\left(P_{g}^{+}\right)$coefficient values of $\mu$, estimated across all studies, using a Chi-square test (equations $2 \mathrm{a}$ and $2 \mathrm{~b}$ ):

$$
\begin{aligned}
& P_{g}^{+}=\frac{\sum_{s} \mathbf{1}_{\mathbb{R}^{+}}\left(\mu_{s, m, f, g, v *}\right)}{\sum_{s} \mathbf{1}_{\mathbb{R}}\left(\mu_{s, m, f, g, v *}\right)} \\
& P_{g}^{-}=\frac{\sum_{s} \mathbf{1}_{\mathbb{R}}\left(\mu_{m, g, v *}\right)}{\sum_{s} \mathbf{1}_{\mathbb{R}}\left(\mu_{s, m, f, g, v *}\right)}=1-P_{g}^{+}
\end{aligned}
$$

Where $\mathbb{R}^{+}$and $\mathbb{R}^{-}$are respectively the subsets of positive and negative values belonging to the set of real numbers, $\mathbb{R}$, and $\mathbf{1}_{A}(\mu)$ is the indicator function defined as:

$$
\left\{\begin{array}{l}
\mathbf{1}_{A}(\mu)=1, \text { if } \mu \in A \\
\mathbf{1}_{A}(\mu)=0, \text { if } \mu \notin A
\end{array}\right.
$$

When $P_{g}^{+}$is significantly greater than 0.5 ( $p$-value $<0.05$ ), fishers tend on average to select options where explanatory variable $v^{*}$ of driver group $g$ has a high value, which is hereby referred to an "attraction" effect. In contrast, fishers make average choices associated with a low v* value when $P_{g}^{+}$ is significantly lower than 0.5 ("repulsion" effect).

This analysis was carried out on the full data set (Table 1), but also for each fleet (active demersal, passive demersal and pelagic) separately if there were enough observations to do so, resulting in the calculation of $P_{f, g}^{+}$and $P_{f, g}^{-}$.

\section{Short-term or long-term decisions?}

We analysed whether fishers are more influenced by recent, or short-term, information (i.e. from previous month, day, or trip) or by long-term information (i.e., from previous year). In principle, short-term and long-term information could be considered for all drivers groups. However, as a result of data availability, only tradition (past effort) was considered to compare the respective influence of long-term and short-term information. This analysis was carried out for passive and active demersal fleets only, because the effects of short-term and long-term drivers were not tested simultaneously in studies of pelagic fleets. 
First, we calculated Score s,m, $f, g_{\text {for }} f \in\{$ "passive fleet","active demersal fleet" $\}$ and for $g=$ "tradition" similar to Section 2.3. However, instead of applying the "Max" function of Equation (1) to all variables $v$ belonging to $g$, we applied it to two subsets of $g$ consisting of short-term drivers ( $g \_s t$ ), or longterm drivers $\left(g_{-} l t\right)$, resulting in Score $e_{s, m_{f}, g_{-} s t}$ and Score $_{s, m_{,}, g_{-} l t}$. The relative influence for each fleet type, long or short-term, was then investigated by analysing the logarithm of the ratio ( $\operatorname{Ratio} 1_{s, m, f}$ )

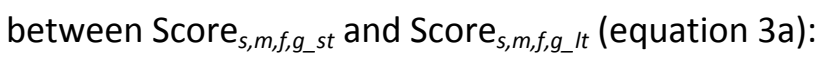

Ratio $_{s, m, f}=$ Ratio $_{s, m, f, g=t r a d i t i o n}=$ Score $_{s, m, f, q_{-} s t} /$ Score $_{s, m, f, g_{-} l t}$

We then evaluated the overall influence of long-term versus short-term information on fisher decisions by analysing Ratio1 with a Generalized Linear Model (GLM), applied to the tradition driver group using Equation (3b) (Table 3).

$\log \left(\right.$ Ratio $\left._{s, m, f}\right) \sim$ Fleet $_{f}+$ Method $_{m}+\varepsilon_{s, m, f}$ with $\varepsilon \sim N\left(0, \sigma^{2}\right)$ and $\sigma^{2}$ the variance of $\varepsilon$

Method $_{m}$ represents the effect of model type, as used in study $s$. This factor has been added to the GLM to separate the potential impacts of the method from the response of the fleet type Fleet $f$. The normality hypothesis was tested with the Shapiro Wilk test and q-q plots.

What is the relative influence of expected gross revenue and of other drivers on fisher behaviour?

Due to varying model complexities and structures, the scores of the variables belonging to the same drivers group could not be compared directly across the different case studies. To make the drivers influence comparable across case studies, we calculated the ratios of the scores among variables belonging to two different groups within the same model, instead of considering the absolute score values. Here, the relative importance of revenue was compared to other key drivers selected in Section 2.2. It may be assumed that commercial fishers act as economic agents, such that their decisions aim to maximize their profit. As economic agents, they can be expected to seek strategies 
that improve their gross revenue while also taking into account the expected costs of fishing and a number of other drivers that have also been shown to influence decision-making. However, detailed costs data are difficult to collect and expected profit is often approximated by gross revenue and/or the value per unit of effort (VPUE) (Marchal et al. 2007; Tidd et al. 2015; Vermard et al. 2008). The importance of the other drivers (fishing costs, attitude towards risk, habits, targeting, and density of other vessels) was tested relative to expected gross revenue. Two different questions were considered, on the one hand (i), how important are the different drivers, overall, compared to expected revenue and, on the other hand (ii), how the relative importance of the different drivers in predicting behaviour could differ across fishing fleets. Both questions were addressed using GLM analyses of scores ratios, using a methodology similar to that presented in Section 2.4.2. For each model, fleet and driver group other than revenue, we thus calculated the ratio ( $R$ atio $2_{s, m, f, g}$ ) of the score of each alternative driver over the score of revenue (Equation 4a):

Ratio $_{s, m, f, g}=$ Score $_{s, m, f, g \neq r e v e n u e} /$ Score $_{s, m, f, g=\text { revenue }}$

In relation to question (i), we carried out a GLM analysis of Ratio2 combining all fleet categories together, to separate out the effects of the modelling method and of the different driver groups (Groups $)$ ) except revenue $(g \neq$ revenue), equation $(4 b)$ :

$\log \left(\right.$ Ratio2 $\left._{s, m, f, g}\right) \sim \operatorname{Groups}_{g}+$ Method $_{m}+\varepsilon_{s, m, f, g}$, with $\varepsilon \sim N\left(0, \sigma^{2}\right)$ and $\sigma^{2}$ the variance of $\varepsilon$

To address (ii), we conducted five GLM analyses of Ratio2, one for each non-revenue drivers group separately, to evaluate the respective effects of fleet categories and modelling methods (equation 4c):

$\log \left(\right.$ Ratio2 $\left._{s, m, f, g}\right) \sim$ Fleet $_{f}+$ Method $_{m}+\varepsilon_{s, m, f, g}$, with $\varepsilon \sim N\left(0, \sigma^{2}\right)$ and $\sigma^{2}$ the variance of $\varepsilon$ 
The residuals from both models were tested for normality, using Shapiro Wilk test and q-q plots.

Not all variable types were present simultaneously in each paper reviewed. Due to this lack of consistency in available information, the analysis of the ratio between the effect of one driver group and that of revenue was only performed when both were investigated in the same paper. As a result, the set of case studies considered varied depending on which driver was analysed (Table 3).

\section{$\underline{\text { Results }}$}

\section{Attraction or repulsion?}

The proportions of signs of the coefficients for each fleet and driver group are shown in figure 1 . As a result of data availability, the chi-square analysis of the proportion of positive coefficients estimated for different explanatory variables could be performed only for demersal active fleets and for all fleets combined (Table 4). For the active demersal fleet, the analysis could be performed for all driver groups, except risk. For the passive demersal fleet, the analysis could only be carried out with expected revenues. There was not sufficient data to conduct sign analysis with the pelagic fleet category separately. All of the proportions tested are significantly different from 0.5 except for the risk-taking group (Table 4).

For the entire fleet and the active demersal fleet specifically, the effects of vessel density, revenue, species targeting and tradition are mainly positive ("attraction" group), while costs have an overall negative effect ("repulsion" group) (Figure 1). Expected revenue also has a positive effect for passive demersal fleets. Risk-taking and risk-averse attitudes were found in similar proportions across the different studies and fleets under investigation.

\section{Short-term or long-term decisions?}

Each of the three models explains $45 \%$ of the variability in the data. More than half of explanatory power stems from the fleet type, and the remaining part by the RUM Method being applied (Table $5)$. Both factors are found to have statistical influence $(p<0.05)$. The Shapiro-test and visual 
inspection of the $Q-Q$ plot both suggest that residuals are normally distributed. Active demersal fleets seem to be more influenced by previous year knowledge and seasonal cycles than by more recent information. In contrast, passive demersal fleets seem to be more influenced by information on the most recent circumstances of the fishery.

\section{What is the relative influence of expected gross revenue and of other drivers on fisher behaviour?}

We first investigated the relative importance of expected revenue compared to other drivers, for all fleets combined (Table 6). 50\% of the variability is captured by the model, most of which being explained by the drivers (and $1 \%$ by the RUM method used) (Table 6 ). The residuals are normally distributed. Overall, revenue seems more influential than risk-taking, but it is less important than species-targeting and tradition (Table 6). Revenue is given a similar weight as fishing costs and the density of other vessels in the prediction of choices.

We then investigated whether fishers from different fleets respond to different drivers in the same way (Table 7). We obtain an adjusted $\mathrm{R}^{2}$ above $50 \%$ for models $2-5$, while model 1 has a lower adjusted $\mathrm{R}^{2}$ of $31 \%$ (Table 7). Model 2's adjusted R-square is close to $100 \%$ due to few observations. Therefore, the influence on fishers' behaviour of risk-taking relative to expected revenue, as derived from model 2 , is considered highly uncertain. The main part of the variability is explained by the fleet type except for model 5, and the residuals are normally distributed. The Method factor has not been considered in model 3, because species targeting and expected revenue are investigated simultaneously only in conditional logit approaches.

To help interpret model outcomes, we show the estimated coefficients drawn from each fleet type within a pentagon-shaped radar plot (Figure 2). The centre of the polygon is associated to the revenue group, while each of its five summits is associated clockwise to one of the other driver groups (tradition, vessel density, risk-taking, costs, species targeting). For each non-revenue driver (g), the fleet effect is represented by three dots (one for each fleet type) located on the segment joining the pentagon's centre to its g-specific edge. The closer a fleet's dot to the edge, the higher the importance of the driver relative to revenue for the fleet being considered. Conversely, the closer 
it is to the centre and the larger the effect of revenue relative to the non-revenue driver. Compared to pelagic fleets, demersal fleets are more influenced by tradition and species targeting than by available revenue information. This is particularly true for passive demersal fleets, for which the coefficient estimates associated to these two drivers are highest. However, in comparison to pelagics, demersal fleets are more influenced by available information on expected revenue than by the density of other vessels and risk-taking. No clear differentiation can be observed between the effects of costs relative to revenue across fleets.

\section{Discussion}

A variety of explanatory variables that often differed across case studies were collected and were subsequently classified into six common groups of fisher behaviour drivers (fishing costs, attitude towards risk, expected gross revenue, habits, targeting, and density of other vessels) (Table 2). To accommodate the complexity of each model and the presence of multiple explanatory variables per driver group, only a single explanatory variable per driver was retained in each model. Some assumptions were made to standardize the various inputs and outputs of RUMs, and to enable the comparison of outputs derived from different model structures. Still, consistent patterns emerge from the analyses regarding the relative influence of key drivers on fishing behaviour.

\section{Attraction or repulsion?}

As a result of data availability, the analysis of the sign of the drivers' effects focused only on the entire data set for all fleets and on the active demersal fleet considered separately. The drivers could be categorized into "attraction" and "repulsion" groups. As shown in several studies (Holland and Sutinen 1999; Marchal et al. 2009; Pradhan and Leung 2004; Vermard et al. 2008), fishers tend to make decisions that are in accordance with their habits and from which they expect a greater revenue. Our results bear out these conclusions.

Risk-taking is generally approximated by the influence of variability of past revenues on individual behaviour (Curtis and McConnell 2004; Larson et al. 1999). Fishers are generally seen to prefer 
minimizing risk by looking for alternatives with a more stable expected revenue (Hilborn and Ledbetter 1979; Andersen 1982; Bockstael and Opaluch 1983; Dupont 1993). However, there may be instances where fishers will visit volatile areas and operate uncertain métiers (Mistiaen and Strand 2000). In particular, when harvested stocks are abundant and in good condition, some skippers could be inclined to select more risky options with the hope of earning outstanding returns (van Putten et al. 2013). In this study, fishers' attitudes towards risk (risk-averse or risk-taking) could not be fully evidenced due to data limitations. Still, there is evidence that the behaviour of fishers operating in pelagic fleets may be more risk-prone than that observed in demersal fleets (Campbell and Hand 1999; Mistiaen and Strand 2000), possibly due to the large natural variability of the resources they harvest and the nature of the environment in which they operate (e.g., it may be less risky to deploy fishing gear in the water column than on unknown and potentially rocky grounds).

In fisheries, both resource and spatial competitions occur (Gillis 2003; Marchal et al. 2006; Salthaug et Aanes 2003; Samples 1989). In particular, fishers compete locally for the resource when, in the context of stock depletion, the harvest of one fleet or boat affects the amount of fish left for others (Gillis and Peterman 1998; Rijnsdorp et al. 2000). Spatial competition (or congestion) occurs when vessel crowding reduces fishing efficiency (Gillis 2003; Pet-Soede et al. 2001; Poos and Rijnsdorp 2007; Samples 1989). However, in the papers that were reviewed, the density of other vessels was generally seen by fishers as a source of information rather than a case for spatial competition (e.g., Vignaux 1996). This concurs with the suggestion by Campbell and Hand (1999) that it is common for vessels to share information with others or to track other vessels, notably using the AIS (Automatic Identification System) on-board. The few cases where vessel density had a repulsing (congestion or competition) effect occurred when competing activities were included, such as maritime traffic, aggregate extraction (Marchal et al. 2014) or other fleet types (Hilborn and Ledbetter 1979; Marchal et al. 2014). 


\section{Is fisher behaviour more influenced by seasonal or immediate knowledge?}

As already mentioned, our results confirm that fishers have a tendency to follow past exploitation patterns (Bockstael and Opaluch 1983; Holland and Sutinen 1999). The active demersal fleets seem to favour seasonal over immediate information. By contrast, the passive demersal fleets adhere to their most recent, rather than to their previous year fishing effort distribution. This might reflect that, compared to active demersal fleets, passive demersal fleets are often composed of small polyvalent multi-gear vessels, with a more limited choice-set and a more variable year-to-year fishing activity.

\section{Which drivers for which fleets?}

The relative importance of fisher behaviour drivers differs substantially between demersal and pelagic fleets, even if the conclusions drawn from our analyses should be treated with caution due to the limited amount of fleet dynamics studies having investigated pelagic fisheries.

As expected (Wilson 1990), tradition appeared to be one of the main drivers of fisher behaviour. Before elaborating on this finding, it is perhaps necessary to stress that in this and other fleet dynamics studies, "tradition" really means "repeating past behaviour". This could reflect fishers' knowledge and previous experience, or have a cultural connotation, when fishers persistently visit the same fishing grounds because everyone in their community they belong to has always done so, or evidence some economic anticipation, when changing habits comes at a cost in terms of buying a new vessel, new equipment on-board, or new gears (Holland and Sutinen 2000; Marchal et al. 2014; Valcic 2009; van Putten et al. 2012). However, what is referred to as tradition in fleet dynamics studies also captures the effects of other drivers, which are poorly observable. As highlighted in the review of van Putten et al. (2012), the large explanatory power of tradition could thus be linked to a substantial overlap of this group of drivers with expected revenue. Fishers rarely discover new fishing grounds and fish on fishing grounds which have proven profitable for long periods of time. More generally, the proxies used to reflect tradition and the way they are implemented in fisheries RUM studies, often make it difficult to discriminate between pure habit (state dependence) and 
preference heterogeneity (variation across individuals in the utility that they expect from choosing a particular option) (Smith 2005). State dependence means that past experience does have a genuine influence on fishers' behaviour. Preference heterogeneity, however, implies that past experience seems to affect behaviour only since it is a proxy for temporally persistent, but unobservable, variables.

Despite these caveats, our findings suggest contrasted response patterns across the fleets being investigated, which bear out general fisheries understanding. Thus, compared to active fleets, passive fleets seem to be relatively more influenced by tradition. This observation might be due to vessels rigged with passive gears being generally small and therefore constrained to fish on a more limited spatial extent (closer to the coast) compared to active fleets. Also, passive vessels may be deployed at a particular time of the year or tide, and in a particular locality to target migrating species (e.g. gill nets). Based on the results of this study, pelagic fleets appear to be less driven by traditions than active or passive demersal fleets. This might be because pelagic fleets tend to target patchy and migratory fish, which have a more variable distribution and require exploring greater areas than those covered by demersal fleets.

The importance of species-targeting as a major driver of fisher behaviour, compared to overall revenue, bears out evidence from earlier studies (Marchal et al. 2009; Vermard et al. 2008). Indeed, some fishers are subject to individually granted single-species landing restrictions (e.g., Total Allowable Catches) and also need to land species for which there is a market demand. Those two constraints may explain why demersal fleets target species for which they have quota and a market channel, rather than fish assemblages of a possibly greater value but which they would not be able to sell or even retain on-board. Compared to demersal fleets, pelagic fleets are generally more selective and usually target few species. Therefore, the species targeting effect for pelagic fleets is probably confounded with that of expected revenue, while it is substantially higher in the case of demersal fleets. 
Compared to demersal fleets, pelagics seem more influenced by risk-taking and information drawn from density of other vessels, relatively to expected revenue. Pelagic fleets target fish subject to large spatial fluctuations and spatial patchiness (shoaling). So, the greater consideration of risk-taking in pelagic fleet may be an important component of their harvesting success, although that could have been alleviated in recent years with the increasing use of GPS-tracked FADs and of support vessels, planes or helicopters. Moreover, the information gathered from other fishers allows them to reduce their searching area and make fishing operations more profitable (Vignaux 1996). In contrast, the species targeted by demersal fleets are generally less variable and distributed in a less patchy fashion, such that fleets may be able to rely to a greater extent on habitual fishing and expected revenue. However, this result should be treated cautiously, given the small number of studies focused on pelagic fleets.

\section{Where to from here?}

As shown in van Putten et al. (2012) and in this study, RUMs and discrete-choice models have attracted considerable attention and have indeed proved useful in forecasting fleet dynamics in the short term. Some studies have attempted to couple such models with conceptual ecological models, to forecast long term ecosystem and fisheries futures (Marchal et al. 2013; Girardin 2015). However, RUMs are relatively simple linear and data-driven models, and as such are not expected to capture all the complexity of the various processes engaged in fishers' decision-making, especially when this involves contexts beyond historical observation, which limits their capacity to provide long-term forecasts. RUMs may thus not be well suited when there are major regulatory or environmental changes, and more particularly so when habit variables are strong predictors of fishers' behaviour, hence bringing in an excessive amount of inertia in the system. More conceptual approaches to fleet dynamics modelling building on, e.g., Ideal Free Distribution theory (Rijnsdorp et al. 2000; Gillis 2003), optimal foraging theory (Dorn 2001; Rijnsdorp et al. 2011), game theory (Trisak 2005), vessel trajectory analyses (Bertrand et al. 2005; Marchal et al. 2007; Vermard et al. 2010), or IndividualBased Modelling (Little et al. 2009; Batsleer et al. 2013), could be considered in that context. A 
follow-up to our study could then be to review, for a variety of case studies, the extent to which coupling conceptual fleet dynamics models with existing ecosystem models (see Plaganyi (2007) for a review) could improve their long-term forecasting capacities.

\section{Conclusion}

In this review, a methodology was proposed to summarize, standardize and compare quantitative information collected in the past three decades on fisher behaviour. Only studies applying discretechoice modelling were investigated to highlight the main drivers of fisher behaviour. As expected, the main behavioural driver affecting fishing decisions is tradition, with a particular influence of seasonal patterns in the case of active demersal fleets. However, species targeting may be as influential as tradition in the decision-making process. It is important to note that the relative strength of tradition variables in explaining fishers' behaviour is partly due to difficulties in specifying expected revenue or profit accurately for individual fishers, particularly when there is a lot of information available to them. More research should thus be dedicated to a better quantification of expected revenue/profit and information flow (Abbot and Wilen 2011). Finally, including a larger number of pelagic and passive fleet case studies would be necessary to provide a more complete picture of the decision-making drivers for both types of fleets. The results also point to a need to better understand the reasons for which specific drivers seem to play less important roles than would have been expected in particular fisheries. Such an understanding might also contribute to improving the quality of information on fleet dynamics that can be used in evaluating alternative management strategies for fisheries policy.

\section{Acknowledgements}

The research leading to these results has received funding from the European Union's Seventh Framework Programme for research, technological development and demonstration (FP7/20072013) within the Ocean of Tomorrow call under Grant Agreement No.266445 for the project Vectors 
of Change in Oceans and Seas Marine Life, Impact on Economic Sectors (VECTORS). We also gratefully acknowledge funding from the IFREMER PhD grant system, as well as the support from the Wealth from Ocean Flagship and CSIRO Marine and Atmospheric Research. 


\section{References}

Abbott, K. and Wilen, J.E. (2011) Dissecting the tragedy: a spatial model of behaviour in the commons. Journal of Environmental Economics and Management 62, 386-401.

Allen, P.M. and McGlade, J.M. (1987) Modelling complex human systems: A fisheries example. European Journal of Operational Research 30, 147-167.

Andersen, P. (1982) Commercial fisheries under price uncertainty. Journal of Environmental Economics and Management 9, 11-28.

Andersen, B.S., Ulrich, C., Eigaard, O.R. and Christensen, A.-S. (2012) Short-term choice behaviour in a mixed fishery: investigating métier selection in the Danish gillnet fishery. ICES Journal of Marine Science 69, 131-143.

Arkema, K.K., Abramson, S.C. and Dewsbury, B.M. (2006) Marine ecosystem-based management: from characterization to implementation. Frontiers in Ecology and the Environment 4, 525-532.

Batsleer, J., Poos, J.-J., Marchal, P., Vermard, Y. and Rijnsdorp, A.D. (2013) Mixed fisheries management: protecting the weakest link. Marine Ecology Progress Series 479, 177-190.

Beaugrand, G., Brander, K.M., Alistair Lindley, J., Souissi, S. and Reid, P.C. (2003) Plankton effect on cod recruitment in the North Sea. Nature 426, 661-664.

Berman, M.D. (2007) Modeling spatial choices in ocean fisheries. Marine Resource Economics 21, 375-394.

Bertrand, S., Burgos, J.M., Gerlotto, F. and Atiquipa, J. (2005) Levy trajectories of Peruvian purseseiners as an indicator of the spatial distribution of anchovy (Engraulis ringens). ICES Journal of Marine Science 62, 477-482.

Bockstael, N.E. and Opaluch, J.J. (1983) Discrete modelling of supply response under uncertainty: The case of the fishery. Journal of Environmental Economics and Management 10, 125-137.

Bougherara, D., Grolleau, G. and Mzoughi, N. (2009) Buy local, pollute less: What drives households to join a community supported farm? Ecological Economics 68, 1488-1495.

Branch, T.A., Hilborn, R., Haynie, A.C. et al. (2006) Fleet dynamics and fishermen behavior: lessons for fisheries managers. Canadian Journal of Fisheries and Aquatic Sciences 63, 1647-1668.

Browman, H.I. and Stergiou, K.I. (2004) Perspectives on ecosystem-based approaches to the management of marine resources. Marine Ecology Progress Series 274, 269-303.

Bucaram, S.J., White, J.W., Sanchirico, J.N. and Wilen, J.E. (2013) Behavior of the Galapagos fishing fleet and its consequences for the design of spatial management alternatives for the red spiny lobster fishery. Ocean \& Coastal Management 78, 88-100.

Campbell, H.F. and Hand, A.J. (1999) Modeling the spatial dynamics of the U.S. purse-seine fleet operating in the western Pacific tuna fishery. Canadian Journal of Fisheries and Aquatic Sciences 56, 1266-1277.

Cinar, E.M., Johnson, J. and Palmer, A. (2013) Decision making: Fishing production and fishers in the Black Sea. Fisheries Research 147, 296-303. 
Cohen-Zada, D. and Sander, W. (2008) Religion, religiosity and private school choice: Implications for estimating the effectiveness of private schools. Journal of Urban Economics 64, 85-100.

Curtis, R.E. and McConnell, K.E. (2004) Incorporating information and expectations in fishermen's spatial decisions. Marine Resource Economics 19, 131-143.

Curtis, R. and Hicks, R.L. (2000) The cost of sea turtle preservation: The case of Hawaii's pelagic longliners. American Journal of Agricultural Economics 82, 1191-1197.

Daskalov, G.M. and Mamedov, E.V. (2007) Integrated fisheries assessment and possible causes for the collapse of anchovy kilka in the Caspian Sea. ICES Journal of Marine Science 64, 503-511.

Daw, T. and Gray, T. (2005) Fisheries science and sustainability in international policy: a study of failure in the European Union's Common Fisheries Policy. Marine Policy 29, 189-197.

Degnbol, P., Gislason, H., Hanna, S., Jentoft, S., Raakjær Nielsen, J., Sverdrup-Jensen, S. and Clyde Wilson, D. (2006) Painting the floor with a hammer: Technical fixes in fisheries management. Marine Policy 30, 534-543.

Dickey-Collas, M., Nash, R.D.M., Brunel, T. et al. (2010) Lessons learned from stock collapse and recovery of North Sea herring: a review. ICES Journal of Marine Science 67, 1875-1886.

Dorn, M.W. (2001) Fishing behavior of factory trawlers: a hierarchical model of information processing and decision-making. ICES Journal of Marine Science 58, 238-252.

Dowling, N.A., Wilcox, C. and Mangel M. (2015) Risk sensitivity and the behaviour of fishing vessels. Fish and Fisheries 16, 399-425.

Dupont, D.P. (1993) Price uncertainty, expectations formation and fishers' location choices. Marine Resource Economics 8, 219-247.

Eales, J. and Wilen, J.E. (1986) An examination of fishing location choice in the pink shrimp fishery. Marine Resource Economics 2, 331-351.

Eggert, H. and Tveteras, R. (2004) Stochastic production and heterogeneous risk preferences: commercial fishers' gear choices. American Journal of Agricultural Economics 86, 199-212.

Ettema, D., Bastin, F., Polak, J. and Ashiru, O. (2007) Modelling the joint choice of activity timing and duration. Transportation Research Part A: Policy and Practice 41, 827-841.

Fulton, E.A., Smith, A.D.M., Smith, D.C. and van Putten, I.E. (2011) Human behaviour: the key source of uncertainty in fisheries management. Fish and Fisheries 12, 2-17.

Fulton, E.A., Smith, A.D.M., Smith, D.C. and Johnson, P. (2014) An integrated approach is needed for ecosystem based fisheries management: Insights from ecosystem-level management strategy evaluation. PLOS ONE 9, e84242.

Garcia, S.M. and Cochrane, K.L. (2005) Ecosystem approach to fisheries: a review of implementation guidelines. ICES Journal of Marine Science 62, 311-318.

Garcia, S.M., Zerbi, A., Aliaume, C., Do Chi, T. and Lasserre, G. (2003) The ecosystem approach to fisheries: issues, terminology, principles, institutional foundations, implementation and outlook. FAO Fisheries Technical Paper No. 443. Rome, FAO, 71 pp. 
Gillis, D.M. (2003) Ideal free distributions in fleet dynamics: a behavioral perspective on vessel movement in fisheries analysis. Canadian Journal of Zoology 81, 177-187.

Gillis, D.M., and Peterman R.M. (1998) Implications of interference among fishing vessels and the ideal free distribution to the interpretation of CPUE. Canadian Journal of Fisheries and Aquatic Sciences 55, 37-46.

Girardin, R. (2015) Ecosystem and fishers' behaviour modelling : two crucial and interacting approaches to support Ecosystem Based Fisheries Management in the Eastern English Channel. Thèse de doctorat de l'Université Lille 1, 297 pp.

Girardin, R., Vermard, Y., Thébaud, O., Tidd, A. and Marchal, P. (2015) Predicting fisher response to competition for space and resources in a mixed demersal fishery. Ocean \& Coastal Management 106, 124-135.

Glick, P. and Sahn, D.E. (2006) The demand for primary schooling in Madagascar: Price, quality, and the choice between public and private providers. Journal of Development Economics 79, 118-145.

Gracia, A. and de Magistris, T. (2008) The demand for organic foods in the South of Italy: A discrete choice model. Food Policy 33, 386-396.

Greene, W.H. (2003) Econometric analysis, Pearson Education, Australia.

Greene, W.H., and Hensher, D.A. (2003) A latent class model for discrete choice analysis: contrasts with mixed logit. Transportation Research Part B: Methodological 37, 681-698.

Hardin, G. (1968) The tragedy of the commons. Science 162, 1243-1248.

Hensher, D.A. and Greene, W.H. (2003) The mixed logit model: The state of practice. Transportation 30, 133-176.

Hilborn, R. (2007) Managing fisheries is managing people: what has been learned? Fish and Fisheries $8,285-296$.

Hilborn, R. and Ledbetter, M. (1979) Analysis of the British Columbia salmon purse-seine fleet: Dynamics of movement. Journal of the Fisheries Research Board of Canada 36, 384-391.

Hjermann, D., Fisher, J.A.D., Rouyer, T., Frank, K.T. and Stenseth, N.C. (2013) Spatial analysis of North Sea cod recruitment: concurrent effects of changes in spawning stock biomass, temperature and herring abundance. Marine Ecology Progress Series 480, 263-275.

Holland, D.S. and Sutinen, J.G. (1999) An empirical model of fleet dynamics in New England trawl fisheries. Canadian Journal of Fisheries and Aquatic Sciences 56, 253-264.

Holland, D.S. and Sutinen, J.G. (2000) Location choice in New England trawl fisheries: Old habits die hard. Land Economics 76, 133-149.

Hutton, T., Mardle, S., Pascoe, S. and Clark, R.A. (2004) Modelling fishing location choice within mixed fisheries: English North Sea beam trawlers in 2000 and 2001. ICES Journal of Marine Science $61,1443-1452$.

Koppelman, F.S. and Wen, C.-H. (1998) Alternative nested logit models: structure, properties and estimation. Transportation Research Part B: Methodological 32, 289-298. 
Larson, D.M., Sutton, W.R. and Terry, J.M. (1999) Toward behavioral modeling of Alaska groundfish fisheries: A discrete choice approach to Bering Sea/Aleutian Islands trawl fisheries. Contemporary Economic Policy 17, 267-277.

Leslie, H.M. and McLeod, K.L. (2007) Confronting the challenges of implementing marine ecosystembased management. Frontiers in Ecology and the Environment 5, 540-548.

Little, L.R., Punt, A.E., Mapstone, B.D., Begg, G.A., Goldman, B. and Williams, A.J. (2009) An agentbased model for simulating trading of multi-species fisheries quota. Ecological Modelling 220, 34043412.

Maravelias, C.D., Haralabous, J. and Tsitsika, E.V. (2014) Fishing strategies and the Ecosystem Approach to Fisheries in the eastern Mediterranean Sea. Scientia Marina 78S1, 77-85.

Marchal, P., Andersen, B., Bromley, D. et al. (2006) Improving the definition of fishing effort for important European fleets by accounting for the skipper effect. Canadian Journal of Fisheries and Aquatic Sciences 63, 510-533.

Marchal, P., Poos, J.-J. and Quirijns, F. (2007) Linkage between fishers' foraging, market and fish stocks density: Examples from some North Sea fisheries. Fisheries Research 83, 33-43.

Marchal, P., Lallemand, P. and Stokes, K. (2009) The relative weight of traditions, economics, and catch plans in New Zealand fleet dynamics. Canadian Journal of Fisheries and Aquatic Sciences 66, 291-311.

Marchal, P., De Oliveira, J.A.A., Lorance, P., Baulier, L. and Pawlowski, L. (2013) What is the added value of including fleet dynamics processes in fisheries models? Canadian Journal of Fisheries and Aquatic Sciences 70, 992-1010.

Marchal, P., Bartelings, H., Bastardie, F., et al. (2014) Mechanisms of change in human behaviour. EU FP7 VECTORS project, Grant Agreement No.266445, Deliverable No. D231 193 pp..

McFadden, D. (1974) The measurement of urban travel demand. Journal of Public Economics 3, 303328.

Mistiaen, J.A. and Strand, I.E. (2000) Location choice of commercial fishermen with heterogeneous risk preferences. American Journal of Agricultural Economics 82, 1184-1190.

Peterson, G. (2000) Political ecology and ecological resilience: An integration of human and ecological dynamics. Ecological Economics 35, 323-336.

Pet-Soede, C., Van Densen, W.L.T., Hiddink, J.G., Kuyl, S. and Machiels, M.A.M. (2001) Can fishermen allocate their fishing effort in space and time on the basis of their catch rates? An example from Spermonde Archipelago, SW Sulawesi, Indonesia. Fisheries Management and Ecology 8, 15-36.

Plaganyi, E.E. (2007) Models for an ecosystem approach to fisheries. FAO Fisheries Technical Paper No. 477. Rome, FAO, 2007, 108 pp.

Pomeroy, R.S., Baldwin, K. and McConney, P. (2014) Marine spatial planning in Asia and the Caribbean: application and implications for fisheries and marine resource management. Desenvolvimento E Meio Ambiente 32, 151-164. 
Poos, J.-J. and Rijnsdorp, A.D. (2007) An "experiment" on effort allocation of fishing vessels: the role of interference competition and area specialization. Canadian Journal of Fisheries and Aquatic Sciences 64, 304-313.

Poos, J.J., Quirijns, F.J. and Rijnsdorp, A.D. (2010) Spatial segregation among fishing vessels in a multispecies fishery. ICES Journal of Marine Science 67, 155-164.

Poulsen, N.A., Nielsen, E.E., Schierup, M.H., Loeschcke, V. and Grønkjær, P. (2006) Long-term stability and effective population size in North Sea and Baltic Sea cod (Gadus morhua). Molecular Ecology 15, 321-331.

Pradhan, N.C. and Leung, P. (2004) Modeling trip choice behavior of the longline fishers in Hawaii. Fisheries Research 68, 209-224.

Prellezo, R., Lazkano, I., Santurtún, M. and Iriondo, A. (2009) A qualitative and quantitative analysis of selection of fishing area by Basque trawlers. Fisheries Research 97, 24-31.

Radovich, J. (1982). The collapse of the California Sardine fishery what have we learned? CalCOFI Report 23, 56-78.

Ran, T., Keithly, W.R. and Kazmierczak, R.F. (2011) Location choice behavior of Gulf of Mexico shrimpers under dynamic economic conditions. Journal of Agricultural and Applied Economics 43, 2942.

Rijnsdorp, A.D., Broekman, P.L. van M. and Visser, E.G. (2000) Competitive interactions among beam trawlers exploiting local patches of flatfish in the North Sea. ICES Journal of Marine Science 57, 894902.

Rijnsdorp, A.D., Poos, J.J. and Quirijns, F.J. (2011) Spatial dimension and exploitation dynamics of local fishing grounds by fishers targeting several flatfish species. Canadian Journal of Fisheries and Aquatic Sciences 68, 1064-1076.

Salthaug, A. and Aanes, S. (2003) Catchability and the spatial distribution of fishing vessels. Canadian Journal of Fisheries and Aquatic Sciences 60, 259- 268.

Samples, K.C. (1989) Assessing recreational and commercial conflicts over artificial fishery habitat use: Theory and practice. Bulletin of Marine Science 44, 844-852.

Smith, M.D. (2002) Two econometric approaches for predicting the spatial behavior of renewable resource harvesters. Land Economics 78, 522-538.

Smith, M.D. (2005) State dependence and heterogeneity in fishing location choice. Journal of Environmental Economics and Management 50, 319-340.

Smith, M.D. and Wilen, J.E. (2003) Economic impacts of marine reserves: the importance of spatial behavior. Journal of Environmental Economics and Management 46, 183-206.

Swait, J. and Louviere, J. (1993) The role of the scale parameter in the estimation and comparison of multinomial logit models. Journal of Marketing Research 30, 305.

Tidd, A.N., Hutton, T., Kell, L.T. and Blanchard, J.L. (2012) Dynamic prediction of effort reallocation in mixed fisheries. Fisheries Research 125-126, 243-253. 
Tidd, A.N., Vermard, Y., Marchal, P., Pinnegar, J., Blanchard, J.L. and Milner-Gulland, E.J. (2015) Fishing for space: fine-scale multi-sector maritime activities influence fisher location choice. PLOS ONE 10, e0116335.

Train, K. (2003) Discrete choice methods with simulation (Cambridge, UK: Cambridge University Press).

Trisak, J. (2005) Applying game theory to analyze the influence of biological characteristics on fishers' cooperation in fisheries co-management. Fisheries Research 75, 164-174.

Valcic, B. (2009) Spatial policy and the behavior of fishermen. Marine Policy 33, 215-222.

van Putten, I.E., Kulmala, S., Thébaud, O., Dowling, N., Hamon, K.G., Hutton, T. and Pascoe, S. (2012) Theories and behavioural drivers underlying fleet dynamics models. Fish and Fisheries 13, 216-235.

van Putten, I.E., Gorton, R.J., Fulton, E.A. and Thébaud, O. (2013) The role of behavioural flexibility in a whole of ecosystem model. ICES Journal of Marine Science 70, 150-163.

Vermard, Y., Marchal, P., Mahévas, S. and Thébaud, O. (2008) A dynamic model of the Bay of Biscay pelagic fleet simulating fishing trip choice: the response to the closure of the European anchovy (Engraulis encrasicolus) fishery in 2005. Canadian Journal of Fisheries and Aquatic Sciences 65, 24442453.

Vermard, Y., Rivot, E., Mahévas, S., Marchal, P. and Gascuel, D. (2010) Identifying fishing trip behavior and estimating fishing effort from VMS data using Bayesian Hidden Markov models. Ecological Modelling 221, 1757-1769.

Vignaux, M. (1996) Analysis of vessel movements and strategies using commercial catch and effort data from the New Zealand hoki fishery. Canadian Journal of Fisheries and Aquatic Sciences 53, 2126-2136.

Walters, C. and Maguire, J.-J. (1996) Lessons for stock assessment from the northern cod collapse. Reviews in Fish Biology and Fisheries 6, 125-137.

Wen, C.-H. and Koppelman, F.S. (2001) The generalized nested logit model. Transportation Research Part B: Methodological 35, 627-641.

Wilen, J.E., Smith, M.D., Lockwood, D. and Botsford, L.W. (2002) Avoiding surprises: Incorporating fisherman behavior into management models. Bulletin of Marine Science 70, 553-575.

Wilson, J.A. (1990) Fishing for knowledge. Land Economics 66, 12-29.

Zhang, J., Kuwano, M., Lee, B. and Fujiwara, A. (2009) Modeling household discrete choice behavior incorporating heterogeneous group decision-making mechanisms. Transportation Research Part B: Methodological 43, 230-250. 


\section{Tables}

Table 1: References included in the analysis with a descriptive of their case study. Fleets selections and drivers groups used in studies are displayed. The number of case studies investigated from each reference is displayed. 61 case studies in total have been considered across all 26 references.

\begin{tabular}{|c|c|c|c|c|c|c|c|c|c|}
\hline Reference & $\begin{array}{c}\text { Ref. } \\
\#\end{array}$ & Area & Period & Method & Fleet & $\begin{array}{c}\text { Fleet } \\
\text { categories }\end{array}$ & $\begin{array}{c}\text { Dependent } \\
\text { variable }\end{array}$ & $\begin{array}{l}\text { Drivers } \\
\text { group }\end{array}$ & $\begin{array}{l}\text { No. of } \\
\text { studies }\end{array}$ \\
\hline $\begin{array}{l}\text { (Andersen et } \\
\text { al., 2012) }\end{array}$ & 1 & $\begin{array}{c}\text { Danish North } \\
\text { Sea }\end{array}$ & $\begin{array}{l}1997- \\
2005\end{array}$ & Nested logit & $\begin{array}{l}\text { Gill netters } \\
\quad>12 \mathrm{~m}\end{array}$ & $\begin{array}{l}\text { Passive } \\
\text { dem. }\end{array}$ & $\begin{array}{c}\text { Fishing area, } \\
\text { target } \\
\text { species }\end{array}$ & $\begin{array}{c}\text { Revenue, } \\
\text { Information, } \\
\text { Risk, } \\
\text { Tradition }\end{array}$ & 1 \\
\hline (Berman, 2007) & 2 & $\begin{array}{l}\text { Bering Sea } \\
\text { USA }\end{array}$ & 1998 & $\begin{array}{l}\text { Multinomial } \\
\text { logit, Poisson }\end{array}$ & $\begin{array}{l}\text { Demersal } \\
\text { trawlers }\end{array}$ & Active dem. & Fishing area & $\begin{array}{l}\text { Revenue, } \\
\text { Costs }\end{array}$ & 4 \\
\hline $\begin{array}{c}\text { (Bucaram et al., } \\
\text { 2013) }\end{array}$ & 3 & Galapagos & $\begin{array}{l}2002- \\
2008\end{array}$ & Nested logit & $\begin{array}{l}\text { Lobster } \\
\text { fishery }\end{array}$ & $\begin{array}{l}\text { Passive } \\
\text { dem. }\end{array}$ & $\begin{array}{l}\text { Fishing or } \\
\text { not, fishing } \\
\text { area }\end{array}$ & $\begin{array}{l}\text { Revenue, } \\
\text { Costs }\end{array}$ & 3 \\
\hline $\begin{array}{c}\text { (Campbell and } \\
\text { Hand, 1999) }\end{array}$ & 4 & $\begin{array}{c}\text { Western } \\
\text { Pacific USA }\end{array}$ & $\begin{array}{c}1988- \\
1995\end{array}$ & Nested logit & $\begin{array}{c}\text { Tuna Purse } \\
\text { seiners }\end{array}$ & Pelagic & Fishing area & $\begin{array}{c}\text { Revenue, } \\
\text { Tradition, } \\
\text { Costs }\end{array}$ & 1 \\
\hline $\begin{array}{l}\text { (Curtis and } \\
\text { McConnell, } \\
\text { 2004) }\end{array}$ & 5 & Hawaii USA & 1997 & Nested logit & $\begin{array}{l}\text { Pelagic } \\
\text { longliners }\end{array}$ & Pelagic & $\begin{array}{c}\text { Fishing area, } \\
\text { target } \\
\text { species }\end{array}$ & $\begin{array}{c}\text { Revenue, } \\
\text { Information, } \\
\text { Tradition }\end{array}$ & 1 \\
\hline (Dupont, 1993) & 6 & $\begin{array}{c}\text { Canadian } \\
\text { British } \\
\text { Columbia }\end{array}$ & 1982 & $\begin{array}{l}\text { Multinomial } \\
\text { logit }\end{array}$ & $\begin{array}{l}\text { Seiners, } \\
\text { gillnetters, } \\
\text { longliners }\end{array}$ & $\begin{array}{c}\text { Passive } \\
\text { dem; } \\
\text { Pelagic }\end{array}$ & Fishing area & $\begin{array}{l}\text { Revenue, } \\
\text { Risk }\end{array}$ & 4 \\
\hline $\begin{array}{c}\text { (Eales and } \\
\text { Wilen, 1986) }\end{array}$ & 7 & $\begin{array}{c}\text { California } \\
\text { USA }\end{array}$ & 1976 & $\begin{array}{l}\text { Nested logit, } \\
\text { Logit }\end{array}$ & $\begin{array}{l}\text { Shrimp } \\
\text { trawlers }\end{array}$ & Active dem. & Fishing area & $\begin{array}{c}\text { Revenue, } \\
\text { Costs }\end{array}$ & 2 \\
\hline $\begin{array}{c}\text { (Eggert and } \\
\text { Tveteras, 2004) }\end{array}$ & 8 & $\begin{array}{c}\text { Swedish } \\
\text { west coast }\end{array}$ & 1995 & Mixed logit & $\begin{array}{l}\text { Demersal } \\
\text { trawlers }\end{array}$ & Active dem. & Gear type & $\begin{array}{c}\text { Revenue, } \\
\text { Risk, } \\
\text { Tradition }\end{array}$ & 1 \\
\hline $\begin{array}{c}\text { (Holland and } \\
\text { Sutinen, 1999, } \\
2000)\end{array}$ & $9 ; 10$ & $\begin{array}{c}\text { New England } \\
\text { USA }\end{array}$ & $\begin{array}{l}1990- \\
1993\end{array}$ & Nested logit & $\begin{array}{c}\text { Otter } \\
\text { trawlers }\end{array}$ & Active dem. & $\begin{array}{c}\text { Gear, target } \\
\text { species, } \\
\text { Fishing area }\end{array}$ & $\begin{array}{l}\text { Revenue, } \\
\text { Information, } \\
\text { Risk, } \\
\text { Tradition, } \\
\text { Costs }\end{array}$ & 2 \\
\hline $\begin{array}{c}\text { (Hutton et al., } \\
\text { 2004) }\end{array}$ & 11 & $\begin{array}{l}\text { English } \\
\text { North Sea }\end{array}$ & $\begin{array}{l}1999- \\
2000\end{array}$ & $\begin{array}{c}\text { Conditional } \\
\text { logit }\end{array}$ & $\begin{array}{l}\text { Beam } \\
\text { trawlers }\end{array}$ & Active dem. & Fishing area & $\begin{array}{l}\text { Revenue, } \\
\text { Tradition }\end{array}$ & 1 \\
\hline $\begin{array}{l}\text { (Larson et al., } \\
\text { 1999) }\end{array}$ & 12 & $\begin{array}{l}\text { Bering Sea, } \\
\text { Aleutian } \\
\text { Islands USA }\end{array}$ & $\begin{array}{l}1991- \\
1992\end{array}$ & Logit & $\begin{array}{l}\text { Demersal } \\
\text { trawlers }\end{array}$ & Active dem. & $\begin{array}{l}\text { Gear, target } \\
\text { species }\end{array}$ & $\begin{array}{l}\text { Revenue, } \\
\text { Information, } \\
\text { Risk }\end{array}$ & 1 \\
\hline $\begin{array}{l}\text { (Maravelias et } \\
\text { al., 2014) }\end{array}$ & 13 & $\begin{array}{c}\text { Eastern } \\
\text { Mediterrane } \\
\text { an }\end{array}$ & $\begin{array}{l}2000- \\
2004\end{array}$ & $\begin{array}{l}\text { Multinomial } \\
\text { logit }\end{array}$ & $\begin{array}{c}\text { Purse } \\
\text { seiners }\end{array}$ & Pelagic & Fishing area & $\begin{array}{c}\text { Revenue, } \\
\text { Information, } \\
\text { Tradition }\end{array}$ & 1 \\
\hline $\begin{array}{l}\text { (Mistiaen and } \\
\text { Strand, 2000) }\end{array}$ & 14 & $\begin{array}{c}\text { Gulf and East } \\
\text { Coast USA }\end{array}$ & 1996 & $\begin{array}{c}\text { Multinomial } \\
\text { logit }\end{array}$ & $\begin{array}{c}\text { Pelagic } \\
\text { longliners }\end{array}$ & Pelagic & Fishing area & $\begin{array}{c}\text { Revenue, } \\
\text { Risk }\end{array}$ & 1 \\
\hline $\begin{array}{l}\text { (Pradhan and } \\
\text { Leung, 2004) }\end{array}$ & 15 & Hawaii & $\begin{array}{c}1991- \\
1998\end{array}$ & Mixed logit & $\begin{array}{c}\text { Pelagic } \\
\text { longliners }\end{array}$ & Pelagic & $\begin{array}{l}\text { Gear, target } \\
\text { species }\end{array}$ & $\begin{array}{l}\text { Revenue, } \\
\text { Risk, } \\
\text { Tradition }\end{array}$ & 1 \\
\hline $\begin{array}{l}\text { (Prellezo et al., } \\
\text { 2009) }\end{array}$ & 16 & $\begin{array}{l}\text { VI,VII,VIII } \\
\text { ICES areas } \\
\text { Spain }\end{array}$ & $\begin{array}{l}1996- \\
2002\end{array}$ & $\begin{array}{c}\text { Multinomial } \\
\text { logit }\end{array}$ & $\begin{array}{l}\text { Demersal } \\
\text { trawlers }\end{array}$ & Active dem. & Fishing area & $\begin{array}{l}\text { Revenue, } \\
\text { Risk, } \\
\text { Tradition, } \\
\text { Costs }\end{array}$ & 1 \\
\hline $\begin{array}{c}\text { (Smith and } \\
\text { Wilen, 2003) }\end{array}$ & 17 & $\begin{array}{l}\text { Northern } \\
\text { California } \\
\text { USA }\end{array}$ & $\begin{array}{l}1988- \\
1997\end{array}$ & Nested logit & $\begin{array}{l}\text { Urchin } \\
\text { fishery }\end{array}$ & $\begin{array}{l}\text { Passive } \\
\text { dem. }\end{array}$ & $\begin{array}{c}\text { Fishing or } \\
\text { not, fishing } \\
\text { area }\end{array}$ & $\begin{array}{l}\text { Revenue, } \\
\text { Costs }\end{array}$ & 1 \\
\hline (Smith, 2002) & 18 & $\begin{array}{l}\text { Northern } \\
\text { California } \\
\text { USA }\end{array}$ & $\begin{array}{l}1988- \\
1997\end{array}$ & Nested logit & $\begin{array}{l}\text { Urchin } \\
\text { fishery }\end{array}$ & $\begin{array}{l}\text { Passive } \\
\text { dem. }\end{array}$ & $\begin{array}{l}\text { Fishing or } \\
\text { not, fishing } \\
\text { area }\end{array}$ & $\begin{array}{l}\text { Revenue, } \\
\text { Risk, Costs }\end{array}$ & 1 \\
\hline $\begin{array}{c}\text { (Tidd et al., } \\
\text { 2012) }\end{array}$ & 19 & $\begin{array}{l}\text { English } \\
\text { North Sea }\end{array}$ & $\begin{array}{l}1997- \\
2007\end{array}$ & Mixed logit & $\begin{array}{c}\text { Beam } \\
\text { trawlers }\end{array}$ & Active dem. & Fishing area & $\begin{array}{c}\text { Revenue, } \\
\text { Tradition, } \\
\text { Costs }\end{array}$ & 9 \\
\hline (Valcic, 2009) & 20 & Oregon USA & $\begin{array}{l}1999- \\
2002\end{array}$ & $\begin{array}{c}\text { Heteroscedastic } \\
\text { Extreme Value }\end{array}$ & $\begin{array}{l}\text { Demersal } \\
\text { trawlers }\end{array}$ & Active dem. & Fishing area & $\begin{array}{c}\text { Revenue, } \\
\text { Tradition, } \\
\text { Costs }\end{array}$ & 1 \\
\hline $\begin{array}{l}\text { (Girardin et al., } \\
\text { 2015) }\end{array}$ & 21 & $\begin{array}{l}\text { Eastern } \\
\text { English } \\
\text { Channel }\end{array}$ & $\begin{array}{l}2007- \\
2008\end{array}$ & $\begin{array}{c}\text { Conditional } \\
\text { logit }\end{array}$ & $\begin{array}{l}\text { Demersal } \\
\text { trawlers, } \\
\text { dredgers, }\end{array}$ & $\begin{array}{c}\text { Passive } \\
\text { dem.; } \\
\text { Active dem. }\end{array}$ & $\begin{array}{c}\text { Gear, target } \\
\text { species, } \\
\text { fishing area }\end{array}$ & $\begin{array}{c}\text { Revenue, } \\
\text { Information, } \\
\text { Tradition, }\end{array}$ & 12 \\
\hline
\end{tabular}




\begin{tabular}{|c|c|c|c|c|c|c|c|c|c|}
\hline & & France & & & netters & & & Targeting & \\
\hline $\begin{array}{l}\text { (Tidd et al., } \\
\text { 2015) }\end{array}$ & 22 & $\begin{array}{c}\text { Eastern } \\
\text { English } \\
\text { Channel UK }\end{array}$ & $\begin{array}{l}2005- \\
2010\end{array}$ & Mixed logit & Dredgers & Active dem. & Fishing area & $\begin{array}{l}\text { Revenue, } \\
\text { Information, } \\
\text { Tradition, } \\
\text { Costs }\end{array}$ & 1 \\
\hline $\begin{array}{c}\text { (Marchal et al., } \\
\text { 2014) }\end{array}$ & 23 & $\begin{array}{l}\text { Eastern } \\
\text { English } \\
\text { Channel } \\
\text { Netherland }\end{array}$ & $\begin{array}{l}2002- \\
2010\end{array}$ & Mixed logit & $\begin{array}{c}\text { Demersal } \\
\text { seiners }\end{array}$ & Active dem. & Fishing area & $\begin{array}{l}\text { Revenue, } \\
\text { Information, } \\
\text { Tradition, } \\
\text { Costs }\end{array}$ & 1 \\
\hline $\begin{array}{c}\text { (Marchal et al., } \\
\text { 2014) }\end{array}$ & 24 & $\begin{array}{c}\text { German } \\
\text { Bight, North } \\
\text { Sea } \\
\text { Netherland }\end{array}$ & $\begin{array}{l}2008- \\
2010\end{array}$ & $\begin{array}{c}\text { Conditional } \\
\text { logit }\end{array}$ & $\begin{array}{l}\text { Beam } \\
\text { trawlers }\end{array}$ & Active dem. & $\begin{array}{l}\text { Gear, target } \\
\text { species, } \\
\text { fishing area }\end{array}$ & $\begin{array}{c}\text { Revenue, } \\
\text { Information, } \\
\text { Tradition, } \\
\text { Targeting }\end{array}$ & 8 \\
\hline $\begin{array}{l}\text { (Vermard et al., } \\
\text { 2008) }\end{array}$ & 25 & $\begin{array}{c}\text { Bay of Biscay } \\
\text { France }\end{array}$ & $\begin{array}{l}2000- \\
2004\end{array}$ & $\begin{array}{c}\text { Conditional } \\
\text { logit }\end{array}$ & $\begin{array}{l}\text { Pelagic } \\
\text { trawlers }\end{array}$ & Pelagic & $\begin{array}{l}\text { Gear, target } \\
\text { species, } \\
\text { season }\end{array}$ & $\begin{array}{l}\text { Revenue, } \\
\text { Tradition, } \\
\text { Targeting }\end{array}$ & 1 \\
\hline $\begin{array}{l}\text { (Wilen et al., } \\
\text { 2002) }\end{array}$ & 26 & $\begin{array}{c}\text { Northern } \\
\text { California } \\
\text { USA }\end{array}$ & $\begin{array}{l}1988- \\
1997\end{array}$ & Nested logit & $\begin{array}{l}\text { Urchin } \\
\text { fishery }\end{array}$ & $\begin{array}{l}\text { Passive } \\
\text { dem. }\end{array}$ & $\begin{array}{c}\text { Fishing or } \\
\text { not, fishing } \\
\text { area }\end{array}$ & $\begin{array}{l}\text { Revenue, } \\
\text { Costs }\end{array}$ & 1 \\
\hline Total & 26 & & & & & & & & 61 \\
\hline
\end{tabular}

Table 2: Details of the different explanatory variables within each drivers group used in the studies shown in Table 1. The number of models associated with each drivers group is displayed. The reference numbers are those given in Table 1.

\begin{tabular}{|c|c|c|c|}
\hline $\begin{array}{l}\text { Drivers } \\
\text { group }\end{array}$ & Explanatory variables & Ref. \# & $\begin{array}{l}\text { No. of } \\
\text { studies }\end{array}$ \\
\hline $\begin{array}{l}\text { Vessel } \\
\text { density }\end{array}$ & $\begin{array}{c}\text { Total effort previous days or month ; Total number of trip or vessel ; Total effort of other fleets ; } \\
\text { maritime traffic }\end{array}$ & $\begin{array}{l}1 ; 5 ; 9 ; 10 ; 12 ; \\
13 ; 21-24\end{array}$ & 28 \\
\hline Revenue & $\begin{array}{c}\text { Expected VPUE ratio, profit, catch, quasirent, revenue ; Average catch value, CPUE, VPUE or RPUE the } \\
\text { previous days, month or year ; Total catch previous month ; Fish stock index }\end{array}$ & $1-26$ & 61 \\
\hline Cost & $\begin{array}{l}\text { Distance from home harbor, departing harbor, landing harbor or from effort gravity center ; Distance } \\
\text { between two tows ; Fuel cost or fuel cost time distance }\end{array}$ & $\begin{array}{l}1-4 ; 7 ; 9 ; 10 ; \\
16-20 ; 22 ; 23 ; \\
\quad 26\end{array}$ & 29 \\
\hline Risk & $\begin{array}{c}\text { Variance or Standard deviation (SD) of expected profit, turnover, revenue or RPUE ; Expected revenue } \\
\text { quadratic function; Coefficient of variation (CV) of RPUE the past month or CV of catch value per day } \\
\text { the previous year }\end{array}$ & $\begin{array}{l}1 ; 6 ; 8-10 ; 12 ; \\
\quad 14-16 ; 18\end{array}$ & 13 \\
\hline Targeting & \%CPUE per target species the previous trips or month & $21 ; 24 ; 25$ & 21 \\
\hline Tradition & $\begin{array}{l}\text { \%Effort in each choice the previous month ; number of previous trip with the same choice ; same choice } \\
\text { the previous trips, days, month or year ; no trip the past month ; Effort allocation the previous month or } \\
\text { year }\end{array}$ & $\begin{array}{l}1 ; 4 ; 5 ; 8-11 ; 13 \\
; 15 ; 16 ; 19-25\end{array}$ & 43 \\
\hline
\end{tabular}

Table 3: Cases studies considered per analyses. The reference numbers are the one from Table 1.

\begin{tabular}{c|c|c} 
Analyses & Models & Reference number \\
\hline $\begin{array}{c}\text { Ratio } \\
\text { Short / Long } \\
\text { Term }\end{array}$ & Equation 3b (Tradition only) & $1 ; 9 ; 10 ; 19 ; 21 ; 22 ; 23 ; 24$ \\
\hline & Equation 4b & $1-12 ; 15 ; 17-26$ \\
Ratio & Equation 4c (Concentration) & $1 ; 5 ; 9 ; 10 ; 21 ; 23 ; 24$ \\
Score / Score & Equation 4c (Costs) & $1-4 ; 7 ; 9 ; 10 ; 17-19 ; 22 ; 23 ; 26$ \\
Revenue & Equation 4c (Targeting) & $21 ; 24 ; 25$ \\
& Equation 4c (Tradition) & $1 ; 4 ; 8-11 ; 15 ; 19,21-25$ \\
& Equation 4c (Risk) & $1 ; 6 ; 8 ; 9 ; 10 ; 15$
\end{tabular}


Table 4: Chi square statistic testing, for each fleet, whether the proportion of studies where the effect of a given driver group has a positive effect on fishers' behaviour is significantly different from the proportion of studies where that effect is negative (pvalue: * $<0.05$ ). "- "indicates combinations for which the analysis could not be conducted.

\begin{tabular}{c|cccccc} 
Variable & $\begin{array}{c}\text { Vessel } \\
\text { density }\end{array}$ & revenue & cost & Risk & Targeting & Tradition \\
\hline Entire fleet & $4.17^{*}$ & $47.61^{*}$ & $14.44^{*}$ & 0.82 & $21^{*}$ & $30.86^{*}$ \\
$\begin{array}{c}\text { Active dem. } \\
\text { Passive } \\
\text { dem. }\end{array}$ & $6.37^{*}$ & $29.43^{*}$ & $9 *$ & - & $17^{*}$ & $30.12^{*}$ \\
& - & $8.33^{*}$ & - & - & - & -
\end{tabular}

Table 5: GLM analysis results for the comparison of long-term and short-term scores calculated for the tradition driver group ( $p$-value: $*<0.05)$. The fleet and model effects are shown with standard deviations in bracket.

\begin{tabular}{|c|c|c|}
\hline \multicolumn{2}{|l|}{ Models } & $\begin{array}{l}\text { Effect of short-term } \\
\text { vs. long-term } \\
\text { information }\end{array}$ \\
\hline \multicolumn{2}{|l|}{ nb. Obs } & 30 \\
\hline \multicolumn{2}{|c|}{ Active demersal } & $-0.79 *(0.18)$ \\
\hline \multicolumn{2}{|c|}{ Passive demersal } & $0.69(0.38)$ \\
\hline \multicolumn{2}{|c|}{ Mixed logit } & $0.84 *(0.26)$ \\
\hline \multicolumn{2}{|c|}{ Nested logit } & $0.54(0.40)$ \\
\hline \multicolumn{2}{|c|}{$\mathbf{R}^{2}$ adjusted } & 0.45 \\
\hline \multirow{2}{*}{ Explained variability } & Fleet & $0.32 *$ \\
\hline & Method & $0.21 *$ \\
\hline Shapiro-Wilk test & W (p-value) & $0.95(0.26)$ \\
\hline
\end{tabular}


Table 6: Relative importance of revenue compared to other drivers of fishers' behaviour. Results of GLM analysis of score ratios as a function of variable group types and RUM methods ( $p$-value: * $<0.05)$.

\begin{tabular}{|c|c|c|c|c|}
\hline Variables & Factor levels & Estimates & $\begin{array}{l}\text { Standard } \\
\text { Deviation }\end{array}$ & $\begin{array}{l}\text { Explained } \\
\text { variability }\end{array}$ \\
\hline \multirow{5}{*}{$\begin{array}{l}\text { Score } \\
\text { ratio }\end{array}$} & Vessel density/Revenue & -0.12 & 0.36 & \multirow{5}{*}{$0.48 *$} \\
\hline & Costs/ Revenue & 0.50 & 0.30 & \\
\hline & Risk taking/ Revenue & $-1.14 *$ & 0.39 & \\
\hline & Targeting/ Revenue & $1.54 *$ & 0.41 & \\
\hline & Tradition/ Revenue & $1.17^{*}$ & 0.32 & \\
\hline \multirow{4}{*}{ Methods } & Conditional logit & -0.33 & 0.35 & \multirow{4}{*}{0.01} \\
\hline & Mixed Logit & -0.35 & 0.34 & \\
\hline & Multinomial Logit & -0.43 & 0.47 & \\
\hline & Nested Logit & -0.06 & 0.33 & \\
\hline \multirow{2}{*}{\multicolumn{2}{|c|}{ Shapiro-Wilk test: W (p-value) }} & 0.50 & & \\
\hline & & $0.99(0.31)$ & & \\
\hline
\end{tabular}

Table 7: Relative importance of revenue compared to other drivers of fishers' behaviour, for each fleet type. One model has been performed for each score ratio type. Results of GLM analysis of score ratios as a function of fleet types and RUM methods ( $p$-value: ${ }^{*}<0.05$ ). The fleet and model effects are shown with standard deviations in bracket.

\begin{tabular}{|c|c|c|c|c|c|c|}
\hline \multicolumn{2}{|c|}{ Models } & $\begin{array}{l}\text { Costs / } \\
\text { Revenue }\end{array}$ & Risk/ Revenue & $\begin{array}{l}\text { Targeting/ } \\
\text { Revenue }\end{array}$ & $\begin{array}{l}\text { Tradition/ } \\
\text { Revenue }\end{array}$ & $\begin{array}{c}\text { Vessel density/ } \\
\text { Revenue }\end{array}$ \\
\hline \multicolumn{2}{|c|}{ model \# } & 1 & 2 & 3 & 4 & 5 \\
\hline \multicolumn{2}{|c|}{ nb. Obs. } & 23 & 9 & 18 & 36 & 20 \\
\hline \multicolumn{2}{|c|}{ Active_dem } & $1.19(0.64)$ & $-2.44 *(0.31)$ & $1.21 *(0.17)$ & $0.87 *(0.19)$ & $-0.38 *(0.13)$ \\
\hline \multicolumn{2}{|c|}{ Passive_dem } & $1.30(1.00)$ & $-2.11 *(0.43)$ & $1.57 *(0.36)$ & $1.80 *(0.40)$ & $-0.40(0.23)$ \\
\hline \multicolumn{2}{|c|}{ Pelagic } & $-0.41(1.44)$ & $-0.08(0.45)$ & $0.15(0.62)$ & $-0.14(0.48)$ & $0.97(0.53)$ \\
\hline \multicolumn{2}{|c|}{ Logit } & $-0.72(1.29)$ & - & - & - & $1.72 *(0.46)$ \\
\hline \multicolumn{2}{|c|}{ Mixed logit } & $-1.35(0.79)$ & $-0.34(0.41)$ & - & $-0.15(0.29)$ & $0.85 *(0.34)$ \\
\hline \multicolumn{2}{|c|}{ Nested logit } & $-0.77(0.91)$ & $2.06 *(0.37)$ & - & $-0.10(0.44)$ & $-0.0001(0.28)$ \\
\hline \multicolumn{2}{|c|}{ Multinomial logit } & $-0.66(1.02)$ & $-0.70(0.45)$ & - & - & - \\
\hline \multicolumn{2}{|c|}{$\mathrm{R}^{2}$ adjusted } & 0.31 & 0.99 & 0.79 & 0.63 & 0.52 \\
\hline \multirow{2}{*}{$\begin{array}{l}\text { Explained } \\
\text { variability }\end{array}$} & Fleet & 0.18 & $0.66 *$ & $0.83 *$ & $0.63 *$ & $0.23 *$ \\
\hline & Method & 0.13 & $0.32 *$ & - & 0.08 & $0.42 *$ \\
\hline $\begin{array}{l}\text { Shapiro- } \\
\text { Wilk test }\end{array}$ & $\begin{array}{l}W(p- \\
\text { value })\end{array}$ & $0.98(0.91)$ & $0.96(0.74)$ & $0.98(0.93)$ & $0.97(0.54)$ & $0.96(0.47)$ \\
\hline
\end{tabular}




\section{Figures captions}

Figure 1: Observed proportion of positive coefficients relative to the different RUM explanatory variables (in grey) compared to the negative ones (in black), for each variable group. Those proportions are shown for the entire fishery and each fleet group separately. The total number of observations is indicated with a white colour.

Figure 2: Comparison across fleets of the importance of different (non-revenue) fishers' behaviour driver relative to expected revenue. Each axis represents estimates of the effect of one driver compared to that of revenue. Any point inside the black dotted pentagon line indicates a fleet's preference for a driver group relative to expected revenue. Active demersal fleets are shown in red, passive demersal fleets in blue and pelagic fleets in green. Significant values with $p$-value $<0.05$ are represented others are set to zero. 


\section{Figures}

1)
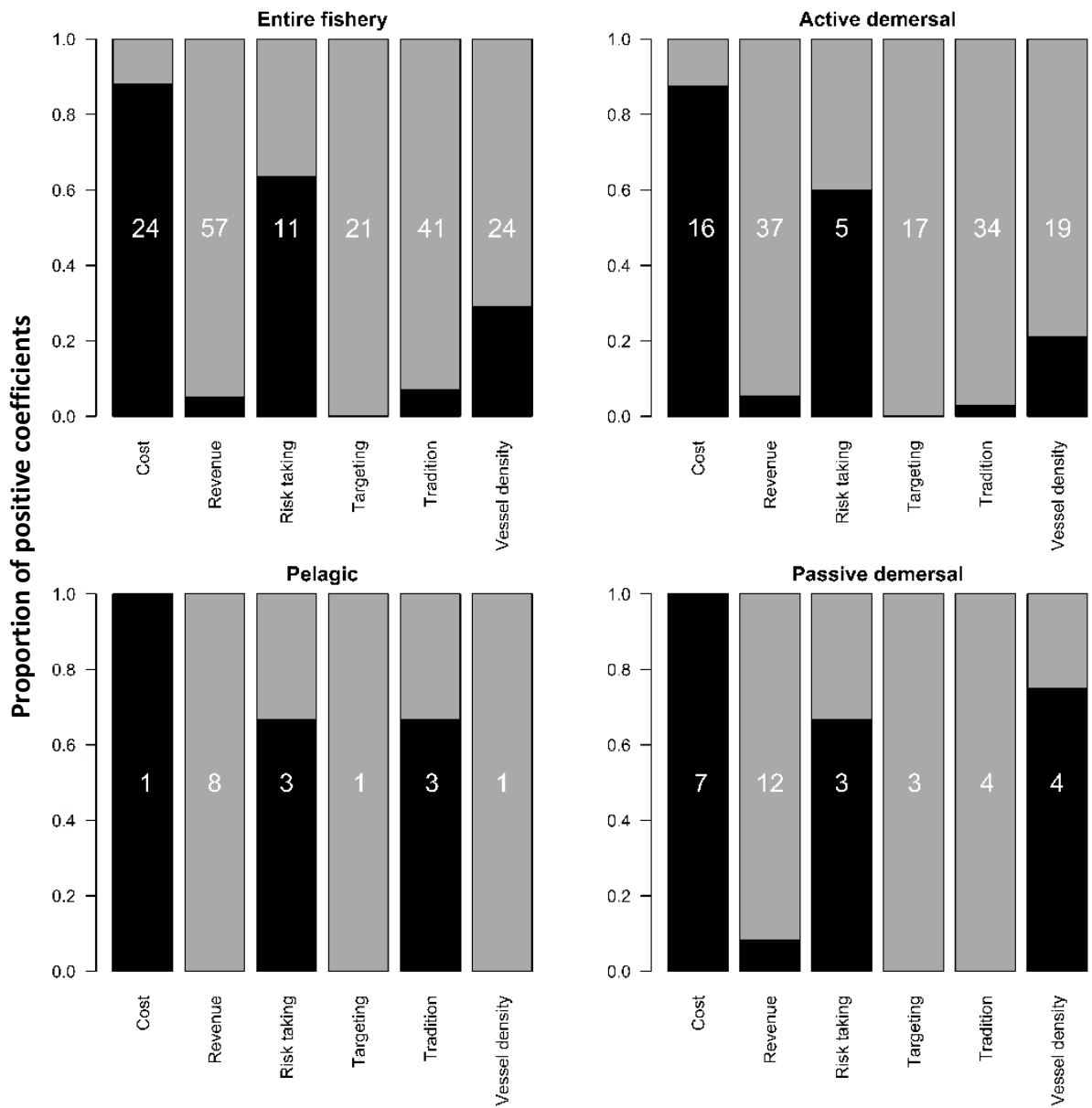
Fisher's behaviour main proxies related to expected revenue

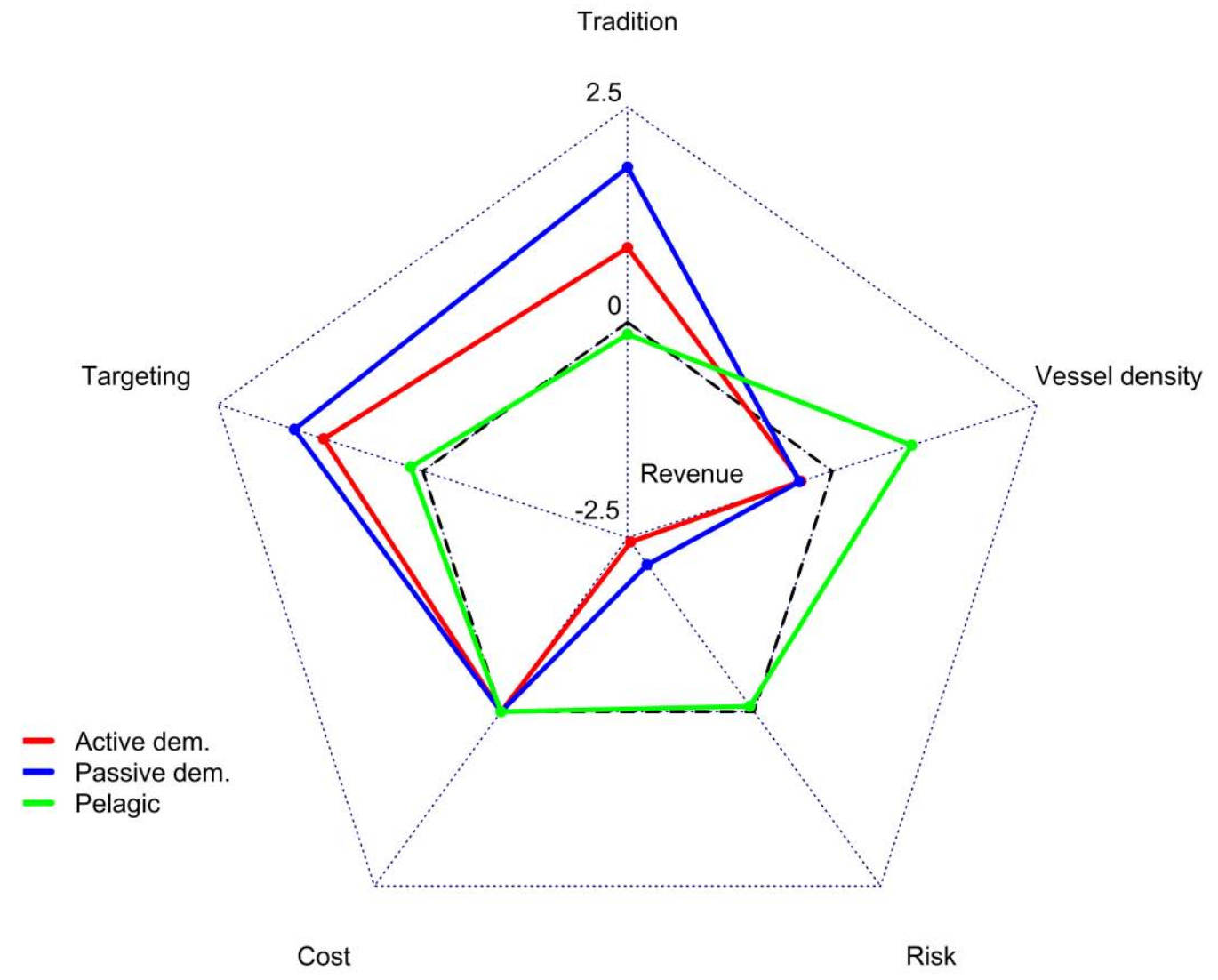

